\title{
Cybercrime and sexual exploitation of children in e-environment in the context of strengthening urban and rural security
}

Andrejs Vilks

Rīga Stradinsš University, Faculty of Law, Riga, Latvia

\begin{abstract}
Among various types of threats to urban and rural security, there has been an increase in cybercrime in recent years, an increase in criminal offenses in the e-environment. This also applies to the sexual exploitation of children in the e-environment. Sexual violence against children in cyberspace is linked to objectively determined factors, such as the development of Internet technologies and their wide availability. The active efforts of children to learn and use the new technologies, the attractiveness of the virtual environment in contrast to the real situation and the ambiguous and in many cases incomprehensible nature, as well as the saturation of pornographic material in the Internet, the weak control of their distribution, should be noted. Due to the increasing availability of the Internet, the expansion of e-services in cities and rural areas is relatively balanced. An Internet user may be at risk in both big cities and in a less populated rural area. Among Internet users the proportion of young people and children is relatively high, which objectively determines their increased victimization potential. Among threats to children related to the e-environment, multiple forms of child sexual abuse, including cyberbullying, sextings, sextorings, cyberstalkings, are increasing.
\end{abstract}

Key words: children, security, e-environment, cybercrime, sexual exploitation.

\section{Introduction}

Sexual abuse of children and sexual exploitation of children, including on the Internet, and child pornography as well, constitute a serious violation of fundamental rights, especially as regards the right of the child to protection and care, necessary for children wellbeing. With the use of new technologies and the Internet, child pornography containing images of sexual abuse of children, including other particularly serious forms of child sexual abuse and sexual exploitation of children, is growing and spreading. On 13 December 2011, the European Parliament adopted Directive 2011/92 / EU on combating the sexual abuse, sexual exploitation of children and child pornography and replacing Council Framework Decision 2004/68/JHA [7]. For serious criminal offenses, such as child sexual abuse and child pornography, a comprehensive approach involving the prosecution of offenders, the protection of child victims and the prevention of appropriate manifestations are essential. In taking any action to combat these offenses, the best interests of the child should be a primary consideration. The Directive provides for criminal liability for deliberate access to child pornography using information or communication technologies. In order to be held liable, a person should have both intentions to enter a site, where child pornography is available, and know that such images are found there. Sanctions should not apply to people who 
have inadvertently accessed child pornography sites. A deliberate offense may, in particular, be recognized by the fact that it was committed repeatedly or by means of paid services. According to Eurostat's requirements, such activities as prostitution in national accounts, which could include child pornography, should now be included [33].

\section{Aim and methods}

To identify the tendency in cybercrimes and sexual exploitation of children in urban and rural areas, their determining factors and prevention options. The sexual exploitation of children in cybercrime in the context of urban and rural environments will be explored using a descriptive method that will analyze the prevalence of this phenomenon, its development trends, determinants, as well as prevention and combating opportunities. The author uses the results of statistical data and optional research in the article by doing the comparative analysis.

\section{Results}

The sexual exploitation of children in the e-environment is influenced by the specific nature of the environment in which they are located. Undoubtedly, the peculiarities of urban and rural environments influence the socialization of individuals, the formation of a value system and socially important activities. The urban environment creates a qualitatively new link between people living in it. This environment has specific features such as: an advanced communication system, including high traffic; a set of industrial enterprises; a broad representation of service companies and entertainment institutions; a large number of people living permanently in urban areas; anonymity of the population that promotes the spread of deviant behaviour. In the urban environment there is a wide availability of new Internet, including informative communication technologies. In the rural environment, on the other hand, one of the greatest benefits of life is environmental safety. Lack of industrial centres and proximity to nature has a positive impact on the environment and the physical and emotional development of individuals, including children. The main disadvantage is that in some rural areas there is not a sufficiently developed system of utilities, which seriously complicates the life of the villagers. Rural areas are directly linked to agricultural production. The decline in agricultural production contributes to unemployment, which in turn leads to problems such as alcohol abuse and crime. Urban and rural environments are now increasingly linked by a unified communicative system, the Internet, and social networks.

Nowadays, the Internet has become the key component of global communications and information infrastructure, along with press, television and telecommunications. The Internet can be seen as one of the most readily available means of communication and information gathering, which is becoming more widely available in Latvia. The quality of communications provided by the Internet and the availability of versatile information resources make a significant contribution to the development of social life by raising the general level of public awareness, improving educational opportunities and methods, and ensuring the availability of free information. The Internet has become a media that effectively gives information and promotes social interaction. Any person can get any information needed. However, the use of the Internet service must also address the challenges posed by these opportunities, with a particular focus on the problems of children's rights over the Internet. In general, cyber threats, including crimes in the e-environment, are increasing in the world, and criminals' criminal assets are increasing. Cybercrime is considered to be at low risk of crime detection. Criminological studies and experts confirm this feature $[13,16]$. One of the most threatened social groups due to insufficient social experience, high 
communicative activity, widely available informative communication technologies (ICT) are children. There are major changes in media use among minors. Minors are increasingly using the media through mobile devices, including online video games which in their turn lead to increased demand for Internet services. The phenomenon of socialization sites is becoming increasingly important both at the individual and the community level. This provides many opportunities for minors, but also poses challenges for child protection. The topicality of the issue is also emphasized in international studies [31].

The growth of child pornography is supported by a number of conditions, rapid technological development, anonymity provided by cyber space and the low cost of consumed resources. Studies have shown that around 10-20\% of minors across Europe could have been sexually abused in childhood, including using modern communicative technologies [23]. Internet monitoring data show that $68 \%$ of the pornographic resources available on the Internet contain child pornography. The most common victims are children aged $7-9$, children aged $10-13-36 \%$, and children under $7-25 \%$. In general, it is possible to distinguish three positions of the rights of children on the Internet: children as Internet users (www pages, chat channels, mailing lists, games); children as content of pornography and erotic web pages (visual material on websites containing pornography); children as a source of threat to the legitimate rights of other Internet users.

\subsection{Trends in the prevalence of sexual violence against children}

When analyzing the problem of sexual violence, including cyber-violence, it is essential to determine the operational content. The Law of 30 May 2013 "Amendments to the Law on the Protection of the Rights of the Child", which came into force on July 4, 2013, clarified the definition of violence, stating that violence is all kinds of physical or emotional cruelty, sexual violence, neglect or other behaviour, that endangers or may endanger a child's health, life, development or self-esteem [10, 11]. There is relatively little empirical research on the risks of children in the e-environment, including sexual ones. The Austrian Safer Internet Centre survey among young Europeans concluded that sexual abuse of children exists in different forms and is common in Europe and Latvia. Almost a third of the interviewed children (30\%) admitted to having been exposed to sextings personally [27].

Although there are studies that point to risk factors that may increase the potential for sexual abuse, the age and background of victims of sexual abuse do not know the limits. Images and videos of child sexual abuse found online include both boys and girls from 0 to 18 years old. Children were under 8 years of age, and $63.40 \%$ of those children were under the age of 8 years of age. When evaluating reports for its purpose, the Canadian Child Protection Centre found that children under 12 years of age represented $78.30 \%$ of their team's pictures and videos, and $63.40 \%$ of these children were under 8 years of age [3]. In the same material, they found that $80.42 \%$ of the children were girls and $19.58 \%$ were boys.

Several images depicting the same child become a record of violence and can be circulating many times, much more than an abuse, resulting in additional adult injuries. Each year, the National Centre for Missing and Missing Children reviews 25 million images. That is 480,769 images per week. Data from the INHOPE Association's 2017 report show that almost two thirds of children $(60,85)$ have been exposed to pornography [15]. INHOPR association data give proof that in 43 countries (including Latvia), 87,930 reports of illegal material on the Internet showing sexual abuse of children were received. These are 259,016 images or videos with illegal content. Most - $(62 \%)$ illegal content was deleted within three days.

In Latvia, as evidenced by the analysis of criminal statistics, sexual abuse against children and the number of crimes committed by minors increased in 2018 [22]. State Police Chief 
I. Kuzis admits that sex offenses among young people are often related to violations committed on the Internet. For example, young people can take sexual pictures that can later be used against them or come into pornographic circulation. Crimes are committed in the Internet, dealing with fraud, illegal pornography and illegal contents. We have to admit, that crimes in cyber environment are committed in a more and more refined manner, criminals use programs such as Skype or WAP and MMS on their mobile phones for camouflage purposes; they create fake profiles in websites, by means of free access online programmes they change computer configurations "fake IP", etc., fake IP addresses for use which essentially makes it harder to detect the mentioned crimes.

On the Latvian Drossinternets.lv report line, in 2018, 180 reports on child sexual abuse material were received on the Internet. It makes $31 \%$ of the total number of received reports. By 28 February, 2019, 5921reports of illegal, harmful Internet content and problem situations on the Internet were received and processed [30].

According to the Riga Christian Shelter study "On Sexual Exploitation of Children in Latvia" at least 1000 children suffer from sexual exploitation per year. It is still admitted that the number is much bigger - up to 5000. We can conclude that sexual abuse of children is a much more serious problem than depicted by official statistical data [26].

As children grow, there is a growing risk of suffering crimes against morals and inviolability. Boys are less likely to suffer from the above-mentioned criminal offenses than girls [28].

\subsection{Most widespread forms of sexual violence against children}

One of children sexual exploitation types is children pornography. According to Law on Pornography Restriction Section 1 children pornography is a pornographic performance in which a child is involved, or a material of pornographic character in which a child is depicted or described [29]. Any picture or a material is considered as children pornography in which:

a) A child who is involved in sexual activities, a child completely or partially without clothing in a sexual pose or in clothing of an obscene nature is depicted or described;

b) A person having the appearance of a child who is involved in the activities mentioned in the sub-Clause 1 "b" and "c", whose genitals are fully or partially depicted, or described;

c) There are realistic images with an actually non-existent child's genitals who is involved in the activities specified in sub-Clause "b" and "c" or presented in a manner specified in sub-Clause "a".

Transmission of photographic pictures of sexual character is the threat of sexual exploitation. The Criminal Law of the Republic of Latvia Section 166 provides for "punishment for downloading, acquisition, importation, production, public demonstration, advertising or other distribution of such pornographic or erotic materials as relate or portray of the sexual abuse of children" [13]. In Latvia, the use of online social networking sites with smart-phones and tablets is becoming more and more common, encouraging young people to participate in the production of pornographic material and the transmission of child pornography graphic files.

Cyberbullying is becoming more and more common among forms of sexual violence. Modern children and young people choose to fight each other using modern technology and the Internet. For example, pupils use smart-phones to photograph a classmate half-clothed in a dressing room and then publish a picture in Facebook to attract general attention. Usually the classmates actively share such pictures with the whole school to make fun of the unhappy victim. Research shows that one fifth of youngsters $(21.9 \%)$ have been exposed 
to virtual terror - cyberbullying [17]. The research done in Europe among 14-17 teenagers reveals alarming conclusions - every fifth teenager in Europe has experienced bullying and mockery in the Internet. More than half (63\%) of European teenagers admitted that they are contacting strangers in the Internet, but every third one has met such strangers. Virtual terror should by no means be considered a minor phenomenon. More than half of schoolchildren surveyed (53.5\%) who had experienced it themselves, indicated that bullying and mockery in the Internet had very negatively affected their psyche. It is interesting that teenager cyberbullying victims may be both boys, and girls, though girls are attacked more, and with sexual motivation.

Cyberstalking is seen to be another form of sexual abuse, which can be defined as cybertracking by using the Internet environment, or other electronic devices [6]. It may include defamation, false accusations, and identity theft, as well as the risk of rape. Intimate partner cybercrime is the online persecution of the current or former romantic partner. Cyberstalking aims to control the victim to promote social isolation and addiction. Stalkers can be an online stranger or a person who knows the victim or the target audience. It can send repeated offensive or threatening e-mail messages to its victims, monitor or disrupt the use of their e-mails, and use the victim's account to send e-mail to others. They can also use the Internet to research and collect personal information about the victim to persecute him [20].

\subsection{Factors determining sexual violence in children in the e-environment}

In order to be able to successfully prevent and combat the sexual exploitation of children in the e-environment, as well as in urban and rural environments, it is essential to identify the determinants of this crime. Factors of children sexual exploitation in the e-environment can be differentiated by several, to our mind, essential criteria. First of all, depending on the scope of factors, we can divide into: 1) global factors (mega-environment); b) macroenvironmental factors (mainly characteristic for the national level in macro-environment); c) micro-environmental factors which are characteristic for specific subjects whose rights are violated (children, their parents).

As to the first fact group, it is important to separate a fast Increase of Information and Communication Technologies and the Widening of their Applications. ICT have become the basis for economic growth and it is an important resource which is used in all spheres in economics and communication [5]. Representatives from the UNO International Telecommunications Union - ITU have published the data on prognoses in the information and technology fields and their consumption in the world. The prognosis is that at the end of 2018 slightly more than half or 3.9 billion of world population will use the Internet [32]. At the end of 2018 the point will be reached when more than or $51.2 \%$ of world population will use the Internet. Broad access to ICT determines that the e-environment more often is used by persons prone to sexual violence against children, developing sexual-type platforms, children pornography websites, etc., as well as minors who are active Internet users, at the same time getting acquainted with the erotic and pornographic materials on the site.

Corresponding but more pronounced tendencies are observed at macro, national level. Thus, the number of regular Internet users (at least once a week) in 2018 reached 81\% [14]. More commonly the Internet users are students and schoolchildren. Each year the Internet availability in the territory of Latvia is increasing. The Internet is most often available in households in Latvian cities (83\%). In the rural areas the Internet availability is increasing year by year - in 2018 it had reached $78 \%$, this indicator, comparing to 2017 has increased by five percentage points. In households of Latgale region it was 74\%. Compared to 2017, the fastest increase in the Internet access was observed in Latgale region, where it grew by five percentage points. 
In micro-environment, no doubt, wide ICT and the Internet availability are observed. The practice of its use is related to the traditions, acquired and accumulated cultural values of the particular social groups, families, including children, the level of legal consciousness. It is necessary to pay attention once again to the fact that the sexual exploitation of children in the e-environment, in both the city and the rural environment, has a very high latency. Sexual abuse against children is related to the time spent by minors on computers, tablets, intensive use of mobile devices. In essence, the virtual environment largely replaces the real one. It is basically the lack of emotional support at school, unfavourable conditions in the family, inadequate child occupancy and poor control. There may be sexually explicit elements in the family, alcohol or drug abuse by parents, and passion for gambling. Poverty is an obstacle to the development of children, and so is poverty in the family. Poor and low-income families are often unable to pay for school supplies for children, out-of-school social and cultural events, leading to a delay in children's social development [21]. Sociological research also mentions the impact of poverty on violations of children's rights, including sexual violence against them [4]. The question arises of how poverty can affect sexual abuse of children in the e-environment? First of all, a poor family is not able to ensure the diversity of children's education and interest development activities. As in the city, diverse ICTs are widely used in rural areas as well. In the current circumstances, unlimited availability of large resources is not required. Secondly, inadequate material resources determine limited satisfaction of vital needs and the emergence of socially disadvantaged families, which constitute weak child control, including the use of mobile devices. Poverty has an economic, social, political and cultural aspect. In general, it threatens human rights- economic (right to work and sufficient income), social (access to health and education), political (freedom of thought, expression and association) and culture (right of residence), cultural identity and engagement in community cultural life.

Factors contributing to the increase in child sexual abuse in cities and rural areas in the e-environment can also be divided into the following groups: a) Technogenic factors: Wide availability of the Internet; Increased Internet download speed; number of users, including minors; ICT modernization; b) cultural environmental factors: accessibility of social services; level of socio-economic development; c) factors characterizing the personality of children. Opportunities to prevent child sexual abuse in the e-environment are lower in rural areas than in cities, which is associated with a lack of control resources.

\subsection{Aspects of preventing and combating the sexual exploitation of children in the e-environment}

In the context of preventing and combating the sexual exploitation of children in the eenvironment, the following aspects need to be addressed: a) legal; (b) promoting the principle of self-regulation of the provision of Internet services and technical measures; (c) educating the public on safe Internet use and ethics [18].

As regards the legal aspects of preventing and combating the sexual exploitation of children in the e-environment, it is necessary to clarify the legal framework for electronic identification services, to introduce common legally accepted technological as well as security standards, to establish a reliable and viable monitoring system for electronic identification services as part of from a national ICT security monitoring and coordination mechanism. The European Parliament Directive 2011/92 / EU "Combating Sexual Abuse of Children, Sexual Exploitation of Children and Child Pornography and replacing Council Framework Decision 2004/68 / JHA" [7] plays an important role in preventing sexual abuse of children. The Directive defined the necessary activities of the Member States in the 
development of national legal acts and further development of the institutional system. In the context of criminal liability for acts related to pornographic performances, this is the case for activities which are the sexual activities of viewers. On the basis of the aforementioned Directive, the disposition of the first part of Article 166 of the Criminal Law of the Republic of Latvia was supplemented on 15 May 2014 with a new form of pornography - a pornographic performance - which in substance corresponds to pornographic performances, but differs in that pornography is not recorded in video recordings, or in any other material form, but is displayed on-site or live [12]. Thus, personal direct contact between peers with mutual consent is excluded from the definition (amendments to Criminal Law). Child pornography often contains images showing sexual abuse of children by adults. They may also be images showing children involved in sexually explicit conduct, or their genitals, if such images are captured or used primarily for sexual purposes, with or without the child's knowledge. As regards serious forms of sexual abuse and sexual exploitation of children, the national legal framework, as provided for in Directive 2011/92 / EU, should review effective, proportionate and dissuasive sanctions. This applies in particular to the various forms of sexual abuse of children and the sexual exploitation of children, facilitated by the use of information and communication technologies, such as online harassment for sexual purposes on social networking sites. The Directive requires Member States to provide for criminal sanctions in their legislation, subject to the provisions of Union law on combating sexual abuse, sexual exploitation of children and child pornography. The Directive requires that there should be criminal liability for deliberate access to child pornography using information or communication technologies. In order to be held liable, a person must have the intention to enter the site where child pornography is available and know that such images are found there. A deliberate offense may, in particular, be recognized by the fact that it was committed repeatedly or by means of paid services.

Child pornography, that is, images of sexual abuse against children, is a specific type of content that cannot be seen as an expression of opinion. In order to combat this, it is necessary to limit the circulation of child abuse material, ensuring that it is more difficult or impossible for offenders to upload such content on the public Internet. Therefore, it is essential to take proactive measures to remove such content and to apprehend those responsible for making, distributing or downloading images of child sexual abuse. We still have to admit, however, that despite such efforts, the removal of child pornography content from their source is often impossible if the original materials are not in EU countries. In some cases, the removal of materials in the country concerned is a particularly long process. It is necessary for the EU to introduce a single mechanism to block access to websites that have been identified as having child pornography or distributed through these sites within the Union. In order to remove and block child abuse content, cooperation between public authorities should be established and strengthened, in particular with a view to ensuring that correspondence with websites containing child pornography material is as complete as possible and that duplication of work is avoided. Such measures should always take into account the rights of end-users and ensure compliance with existing legal and judicial procedures as well as the provisions of the European Convention for the Protection of Human Rights and Fundamental Freedoms [8] and the Charter of Fundamental Rights of the European Union [2] unprecedented anonymity. Individuals have the opportunity to hide their true identity and personality traits such as their age. Investigative and investigative authorities on child sexual abuse, including cyber crime, and criminal prosecution should provide effective means of investigation. These tools could include special investigation activities, including interception, secret surveillance, including electronic surveillance, bank account monitoring or other forms of financial investigation, taking into account the type and severity of the offenses under investigation. Where appropriate and in accordance with applicable law, such 
means should also include the possibility for law enforcement authorities to use the hidden identity on the Internet.

Thomas Brewsters, a researcher at the Forbes magazine, has drawn attention to the peculiar methods of the US Federal Bureau of Investigation (FBI) to combat child pornography networks [9].

The FBI has used a completely new tactic in the fight against child pornography: taking over the suspects' online identities to enter private groups with illegal content. Agents used the identity of 23-year-old Daxton Hansen from Salt Lake City who used the KitB10 username. From April 12, 2017 to November 13, 2018, the secret FBI agent working for the Salt Lake City agency took over Hansen's online identity. Agents allowed child sexual abuse material on social network Instagram to spread about eighteen months after they had identified a pornographic distributor. This specific operation has two important aspects. First, by using this tactic, it is possible for the police to identify, document and prosecute persons who distribute pornographic material with child images and videos. Secondly, the social networking materials include specific children and young people who are hurting them repeatedly (multiple victimization). In addition, pornographic material continued to be read and downloaded by minors. It has to be admitted that conducting this type of operation should be evaluated by a legal and moral ethical approach. In a study conducted in Latvia in 2018, it was found that every second respondent has encountered violations on the Internet [1].

Among the violations in the Internet there has been found: blackmail or threat thereof; financial fraud schemes; experiencing emotional violence; interacting with pornography material without age-limiting warning. Every seventh (15\%) admits that they are familiar with someone on the Internet who, using a false profile is straying on someone else. At the same time, $39 \%$ of parents have not been interested whether a child has had any negative experiences using the Internet.

Self-regulation and technical measures for the provision of Internet services are sufficiently broad and specific. The widespread availability of the electronic environment in society is inconceivable without the ability to protect the individual, especially children, from the harmful or unwanted content of the Internet and the ability to provide the necessary assistance and support in situations where such harmful web content has or is likely to occur. It is essential to stop access to harmful Internet content as quickly as possible. The Information Society Guidelines state that it is necessary to report to the State Children's Rights Protection Inspectorate on illegal and harmful content on the Internet. State Children's Rights Protection Inspectorate should provide psychologist support to children who have come across harmful information material on the Internet [24]. The Cabinet of by Ministers Order No.581 of 25 August 2009 approved the "Action Plan for the Protection of Minors from Criminal Offenses against Virtue and Intolerance 2010-2013" 1 [25]. This is also evidenced by the problems currently encountered in practice, for example, there is still no solution for dealing with persons who have sexual interest in children and want assistance, there is still insufficient involvement of the Ministry of Health in solving this problem, and there are still not enough solutions for sexual abuse in crime prevention, public, including non-governmental sector involvement in the prevention and detection of these crimes, etc.

In general, the prevention and combating of child sexual abuse in the e-environment is diverse. However, they are fragmented and included in different programs, guidelines and concepts. Political planning documents do not distinguish between the specificities of the social environment, including rural and urban areas. Preventive measures do not take into account the developments in new information technologies. It should be noted that the effectiveness and positive achievements of measures to prevent and combat sexual exploitation of children in the e-environment are underestimated. 


\section{Conclusions}

The sexual exploitation of children in the e-environment in Latvia has not been studied in detail and comprehensively. Children's sexual cyber threats are more widespread than the real environment and have a high latency. Consequently, it is objectively difficult to determine the extent of the harm inflicted on minors in cases of sexual violence in the e-environment. Sexual abuse of children in a virtual environment distorts their socialization process, draws the value of a positive value system, and traumatizes them emotionally and psychically. The forms of sexual exploitation of children are becoming more diverse and refined. With the exception of widespread child pornography sites and links in the e-environment, new forms of juvenile sexual violence - cyberbullying, sextings, sextorings, cyberstalkings are also spreading. We can see that, as the potential for violence increases, more and more children are subjected to sexual violence; the availability and impact of sexual information (erotic and pornographic publications) is intensifying, contributing to the development of deviant norms, ideals and values in children; a decrease in the age of sexual exploitation of children;

Factors determining child sexual abuse are social and technological. They function at global, macro and individual levels. Sexual violence against children in cyberspace is linked to objectively determined factors, such as the development of Internet technologies and their wide availability. The efforts of children to learn and use the new technologies, the attractiveness of the virtual environment, in contrast to the real situation and ambiguous and in many cases incomprehensible circumstances, should be noted. Prevalence of pornographic material in the Internet environment and poor control of their distribution are another factor. The European Parliament Directive 2011/92 / EU" Combating Sexual Abuse of Children, Sexual Exploitation of Children and Child Pornography and replacing Council Framework Decision 2004/68 / JHA' as well as the Criminal Law, which is essential for the prevention of sexual violence against children, it determines responsibility for the sexual exploitation of children. At national level, measures to prevent and combat the sexual exploitation of children in the e-environment are diverse. They are included in various programs, guidelines and concepts. However, political planning documents do not distinguish between the specificities of the social environment, including rural and urban areas. Preventive measures do not take into account the developments in new information technologies, the effectiveness and positive achievements of measures to prevent and combat sexual exploitation of children in the e-environment are underestimated. Additional detailed research is needed on the sexual exploitation of children in the e-environment in cities and rural areas, identifying their security enhancement optimization models.

\section{References}

[1] Aptauja: katrs otrais interneta lietotājs ir saskāries ar pārkāpumiem internetā. Available online at: https://www.tvnet.lv/6516375/aptauja-katrs-otraisinterneta-lietotajs-ir-saskaries-ar-parkapumiem-interneta

[2] Charter of Fundamental Rights of the European Union. Available online at: https:// eur-lex.europa.eu/legal-content/EN/TXT/?uri=celex:12012P/TXT

[3] Child pornography is sexual abuse material. Available online at: https://www . thorn.org/child-pornography-and-abuse-statistics/

[4] Child safety online: global challenges and strategies. Available online at: https://www . unicef-irc.org/publications/650-child-safety-onlineglobal-challenges-and-strategies.html 
[5] Cybersecurity Strategy of the European Union: An Open, Safe and Secure Cyberspace. Available online at: https://eeas.europa.eu/archives/docs/policies/eucyber-security/cybsec_comm_en.pdf

[6] Davis, Joseph A. Stalking Crimes and Victim Protection. Boca Raton, Florida: CRC Press. pp. 3-19. ISBN 978-1420041743

[7] Directive 2011/92/EU of the European Parliament and of the Council of 13 December 2011 on combating the sexual abuse and sexual exploitation of children and child pornography, and replacing Council Framework Decision 2004/68/JHA. Available online at: https://eur-lex.europa.eu/legal-content/EN/TXT/?uri= celex\%3A32011L0093

[8] European Convention for the Protection of Human Rights and Fundamental Freedoms. Available online at: https://www.echr.coe.int/Documents/Convention_ ENG.pdf

[9] Exclusive: What Happened When the FBI Took Over the Instagram And Kik Of A Child Porn Dealer. Available online at: https://www.forbes.com/ sites/thomasbrewster/2019/03/06/exclusive-the-fbi-took-over-theonline-identity-of-a-pedophile-letting-child-porn-spread-for-18months/\#6b2bee875cb1]

[10] Grozījumi Bēnutiesībuaizsardzībaslikumā Available online at https://likumi.lv/ ta/id/265209-grozijumi-bernu-tiesibu-aizsardzibas-likuma

[11] Grozījumi Bērnu tiesību aizsardzības likumā", https://likumi.lv/doc.php?id= 257679

[12] Grozījumi Krimināllikumā. Available online at: https://likumi.lv/ta/id/ 266590-grozijumi-kriminallikuma

[13] Gubene A., Barise L. Kibernoziegumu risks pārvaldes institūcijās . Available online at: http://llufb.llu.lv/Raksti/SZF-raksti-2013/SZF_RAKSTI_III_2013$19-26 \cdot p d f$

[14] Informācijas un komunikācijas tehnoloìiju rādītāji mājsaimniecībās 2018. gadā. Available online at: https://www.csb.gov.lv/sites/default/files/ publication/2018-12/Nr_26_Informacijas_un_komunikacijas_ tehnologiju_lietosana_majsaimniecibas_2018_\%2818_00\%29_LV_0.pdf

[15] INHOPE Annual Report 2017. Available online at: http://www.inhope.org/ tns/resources/annual-reports.aspx]

[16] Internet Organised Crime Threat Assessment 2018. Available online at: https:// www . europol . europa.eu/internet-organised-crime-threat-assessment2018

[17] Kā pasargāt bērnus no virtuālā terora. Available online at: https://www .tvnet.1v/5459102/ka-pasargat-bernus-no-virtuala-terora

[18] Koncepcijas par bērnu tiesību aizsardzību internetā. Available online at: https://likumi.lv/ta/id/68245-par-koncepciju-par-bernu-tiesibuaizsardzibu-interneta

[19] Krimināllikums. Available online at: https://likumi.lv/doc.php?id=88966

[20] Ménard, Kim S., Pincus, Aaron L. (July 1, 2012). "Predicting Overt and Cyber Stalking Perpetration by Male and Female College Students". J. Interpersonal Violence. Seattle, Washington: SAGE Publications 27(11), 2183-2207. doi: 10.1177/08862605 11432144. ISSN 0886-2605. PMID 22203630

[21] Nabadzības riskam pakïauti ceturtdaïa Latvijas iedzīvotāju. Available online at: https://www.tvnet.1v/6501434/nabadzibas-riskam-paklauticeturtdala-latvijas-iedzivotaju 
[22] Noziegumu statistika Latvijā: Pieaug nepilngadīgo noziegumi un seksuālā vardarbība pret bērniem.Availableonlineat: https://bnn.lv/vp-pieaug-nepilngadigonoziegumi-seksuala-vardarbiba-pret-berniem-315183

[23] Par bērnu pornogrāfijas skatīšanos internetā būs bargi sodi. Available online at: https://www.tvnet.1v/5070066/par-bernu-pornografijas-skatisanosinterneta-bus-bargi-sodi

[24] Par Informācijas sabiedrības attīstības pamatnostādnēm 2014.-2020.gadam. Available online at: https://likumi.lv/doc.php?id=260931

[25] Par Rīcības plānu nepilngadīgo aizsardzībai no noziedzīgiem nodarījumiem pret tikumību un dzimumneaizskaramību 2010.-2013.gadam. Apstiprināts ar Ministru kabineta 2009.gada 25. augusta rīkojumu Nr.581. https://likumi.lv/ ta/id/265209-grozijumi-bernu-tiesibu-aizsardzibas-likuma: http://likumi.lv/doc.php?id=196667

[26] Pētījums "Latvijas un citu valstu pieredze darbam ar seksuālajiem noziedzniekiem". http: //www.vpdp.gov.lv/lat/gen/58/828/ - (04.09.2007.)

[27] Pētījums: Sekstings - ierasta parādība bērnu un jauniešu dzīvē. 2011. Available online at: http: //www.bti.gov.lv/lat/aktualitates/?doc $=2692$

[28] Plāns nepilngadīgo aizsardzībai no noziedzīgiem nodarījumiem pret tikumību un dzimumneaizskaramību 2018. - 2021.gadam. Available online at: tap.mk.gov. Iv/doc/2018_08/TMP1_160818_dzimumnoz.858.doc

[29] Pornogrāfijas ierobežošanas likums. Available online at: https://likumi.lv/ doc.php?id=157638

[30] Reports statistics. Drossinternets.lv (Safe Internet) Available online at: https://drossinternets.1v/lv/info/zinojumu-statistika

[31] Risk taking Online Behaviour Empowerment Through Research and Training. Available online at: http://www . childcentre.info/robert/

[32] Vairāk kā puse planētas iedzīvotāju lieto internetu. Available online at: https:// www. bismart. lv/blogs/internets/vairak-ka-puse-planetasiedzivotaju-lieto-internetu-868

[33] Vilks A. Sexual services, drugs and human trafficking, smuggling - in GDP figures: Quality of life indicators. Conference: 5th International Interdisciplinary Scientific Conference on Society, Health, Welfare Location: Riga, LATVIA Date: Nov 26-28, 2014. Available online at: https://apps.webofknowledge.com/full_record. do?product=WOS\&search_mode=AuthorFinder\&qid=9\&SID=C1K1HXPV Jr2uNpU G6Ru\&page $=1 \&$ doc $=2$ 